\title{
Making Choices: Matching Sustainable Funding with Strategic Priorities in Higher Education
}

Feridun Hamdullahpur

\section{Introduction}

Universities around the world-small, large, old, new, regardless of their country of origin - are in a consistent quest to differentiate themselves for global recognition and impact. While almost all of these institutions share a common vision for education, knowledge generation and service, many will characterize themselves as either "education heavy" or "research intensive". These differentiations have created divisions of institutions at a national and global level, attracting certain researchers and students, while their missions for "public good" have not changed since the establishment of the first university nearly 1000 years ago. This public good has only broadened during that time to include their economic, scientific and social impact that have become integral parts of their institutional purpose.

Universities ultimately serve to push society forward. What we have seen in recent decades in that role has broadened exponentially as universities are educating the world's leaders across all sectors and driving the creation of technology, scientific discovery and policy developments to deliver prosperity and advance society.

There is a growing concern in many parts of the world on the short and long-term implications of funding allocations to universities, and also what the short and long-term returns will be of these investments and how they can best maximize economic and social impact. The implications of the COVID-19 pandemic have only exacerbated this evaluation of how to fund vital university operations during a time of economic and societal uncertainty.

This chapter intends to provide an overview of existing models of funding, new trends in expanding resource providers, considerations for how to establish a better understanding of strategic allocation of funds, and explore, briefly,

F. Hamdullahpur $(\bowtie)$

University of Waterloo, Waterloo, Canada

e-mail: president@uwaterloo.ca some of the challenges and opportunities COVID-19 has created for funding research and operations at universities.

\section{Existing Funding Models for Most Common Types of Universities}

Universities around the world are unique in their own ways based on their community, institutional priorities and size.

Regardless of the source or origin of revenue streams, internal allocation of resources can be undertaken in several ways ranging from incremental increases to critically reviewed performance budgeting, depending on the administrative and academic structure of the institution. Here are six of the most commonly used funding models within universities:

- Incremental Funding

- Zero-based Funding

- De-centralized Funding

- Activity-based Funding

- Performance-based Funding

- Centralized Funding.

Each funding model has its advantages and disadvantages that must be weighed by a university and the governing body that both funds and/or oversees the funding of said institutions.

\subsection{Incremental Funding}

Incremental Funding was once the most predominate model for post-secondary funding in the middle of the twentieth century. This model is based on an institution's previous year's budget with a predetermined incremental increase or decrease across the top-level budget [1]. Funding levels in this model are determined through a number of mechanisms 
based on government budget formulas or based on another economic factor, such as the rate of inflation.

Despite its drawbacks, Incremental Funding is widely used because of its simplicity in the budgetary process and predictability within an institution. It does not require long, labor-intensive preparation every year.

While this simplicity has its benefits it also promotes reliance on maintaining the status-quo as opposed to creativity and innovation at the institutional and departmental levels. It further promotes accumulation of unused funds usually spent on non-strategic expenditures. Simply, it provides incremental (usually inflation plus certain percentage) increase on top of the previous year's funding. If an institution decides to implement budget cuts because of a decline in its revenue streams, it is done across the institution applying to all units as opposed to a select number. Special cases of budget allocation requests outside of this process are acceptable, but usually handled on an ad-hoc basis in order to maintain unit equity across the budgetary process.

\subsection{Zero-Based Funding}

Zero-based Funding (ZBF) is perhaps one of the most thorough and also labor-intensive processes that requires more time to build new budgets for every organizational unit with no history to previous budgets. It stresses a clean slate budget with everything from previous years of budgets questioned and forced justification [1].

This process further necessitates itemizing and justification of every salary, on-going, one-time expenditures with no possibility of carry over. For some organizations that have the dedicated resources, this is an effective way of curbing cost escalation as well as ensuring high level of accountability. This approach completely eliminates the entitlement expectation of academic and administrative units and ensures that all allocated funds are fully spent and spent appropriately according to the plan.

The inherent benefit of the ZBF model is in its flexibility to shift priorities year-to-year, allowing for better service outcomes. A study comparing the ZBF model to the traditional Incremental Funding model deduced that the former created higher quality outcomes in providing services [2]. This study, however, was performed at the unit and departmental level, not an institutional level. There are innate challenges to the ZBF model, as well. Using a funding model that is limited in time and receives a complete overhaul annually makes it difficult to develop long-term, multi-year goals, projects and initiatives.

\subsection{De-Centralized Funding}

The De-centralized Funding and budgeting model is based on an institution's overall academic/management structure. This model gives significant autonomy to the university's academic units to allow them to design their own academic plans and priorities so long as they are congruent with those of the university (as is the case here at the University of Waterloo). This model, for an institution's funding, is perhaps closer to a management philosophy than a budgeting strategy. This approach enables the academic units to plan and operate in a federated system with autonomy while being fully accountable for the performance measures and deliverables and allows for a budget which closely follows those priorities.

Thus, the funding an academic unit receives is a reflection of this management structure. While there may be a formula-based variation as to how the tuition and grant revenues are distributed, units receive a total sum of funds at their disposal. They can plan for annual undergraduate and graduate numbers and corresponding faculty recruitment in collaboration with the Provost's office, but, mostly, they do so independently. These units are responsible for their own expenses, in some cases, including space and utility charges. Interdivisional teaching revenues are based on a formula administered through the Provost's office on a fairly even platform to avoid, as best as possible, competition and duplication of resources among academic units.

This approach creates incentives within academic units and non-academic units, in different ways, to strengthen institutional impact and/or meet their strategic goals [3]. For example, Faculty deans and schools are incentivized to explore other revenue sources and philanthropic fundraising, such as alumni and industry donors to meet their specific strategic goals. It is important to note that, budgeting of non-academic and academic support units is done differently because of their inherently different focuses.

While academic and non-academic funding and internal budgeting are done-for the most part_-independently, this relies heavily on an understanding of institutional strategic goals.

\subsection{Activity-Based Funding}

The next type of funding model is the Activity-based Funding $(\mathrm{ABF})$. The ABF model is utilized by a smaller number of institutions as they prefer a model where revenues are aligned with activities with an expectation of maximized 
returns. There are countless $\mathrm{ABF}$ formulas that are created within each organization that leverages the $\mathrm{ABF}$ funding model that are unique to their specific needs.

For example, not all academic or non-academic funding will be tied to an "activity". This includes Faculties or Schools who are sometimes dependent on allocated revenue from tuition that is then divided and distributed. There has been some evidence that the ABF can offer a degree of financial accountability within the units [4]. It allows the reallocation of resources to those areas that are growing, but as a unifying funding model on its own, ABF often does not meet the complex needs of a 21 st-century university.

\subsection{Performance-Based Funding}

A much larger number of institutions prefer the Performance-based Funding (PBF) model instead of ABF. As opposed to incremental adjustments to budget levels or those based on activity, funding within the PBF model is instead based on a number of performance measures.

This is especially critical in jurisdictions where government grants require strict accountability measures coupled with performance expectations, such as employment and graduation rates. Many institutions carry these performance measures into academic units in the form of enrolment targets with entry GPA to SAT scores, retention and graduation rates, external research revenues, publication rates, new startups, and more being common examples.

Studies have shown that although this model of funding can create added benefits around incentivizing change within an institution, its overall, long-term effects are limited [5].

\subsection{Centralized Funding}

Centralized Funding (CF) sits on the opposite end to the de-centralized model in the realm of university funding models. While it removes many benefits of aspiration and strategic thinking-based budgeting, it may be a preferred option in places where the stability and continuity of external funding, predominantly from tuition and government grants, is not sustainable.

Senior administration, in the case of Centralized Funding, is in charge of making all budgetary decisions, including infrastructure, faculty and staff hiring, program expansions, and other resource allocations. This model is usually, with the exception of the de-centralized model, combined with one of the other models to provide flexibility and control at the same time. The rigidity of the Centralized model makes innovation and adaptability difficult and doesn't always allow for the individual strengths of academic and non-academic units to flourish naturally.
Strengths and Weaknesses of Funding Models.

\begin{tabular}{|c|c|c|}
\hline Model & Strengths & Weaknesses \\
\hline $\begin{array}{l}\text { Incremental } \\
\text { funding }\end{array}$ & $\begin{array}{l}\text { - Simple to } \\
\text { implement } \\
\text { - Budget } \\
\text { predictability for } \\
\text { institutional units }\end{array}$ & $\begin{array}{l}\text { - Stifles creativity } \\
\text { and innovation at } \\
\text { institutional and } \\
\text { departmental } \\
\text { levels } \\
\text { - Promotes the } \\
\text { accumulation of } \\
\text { unused funds } \\
\text { usually spent on } \\
\text { non-strategic } \\
\text { expenditures }\end{array}$ \\
\hline Zero-based funding & $\begin{array}{l}\text { - Can curb } \\
\text { escalating costs } \\
\text { - Ensures high level } \\
\text { of accountability } \\
\text { to justify each } \\
\text { item }\end{array}$ & $\begin{array}{l}\text { - Labor intensive to } \\
\text { create new model } \\
\text { every fiscal year } \\
\text { - Limits ability for } \\
\text { institution to do } \\
\text { long-term } \\
\text { planning }\end{array}$ \\
\hline $\begin{array}{l}\text { De-centralized } \\
\text { funding }\end{array}$ & $\begin{array}{l}\text { - Creates autonomy } \\
\text { and individual unit } \\
\text { accountability to } \\
\text { maximize funds } \\
\text { - Accounts for } \\
\text { unique } \\
\text { differentiations } \\
\text { between units, } \\
\text { while not } \\
\text { punishing them } \\
\text { - Allows } \\
\text { institutional units } \\
\text { to contribute to } \\
\text { institutional } \\
\text { strategic goals } \\
\text { while maintaining } \\
\text { individual } \\
\text { strengths } \\
\text { - Allows for unique, } \\
\text { unit-based projects } \\
\text { to develop more } \\
\text { freely }\end{array}$ & $\begin{array}{l}\text { - Positive outcomes } \\
\text { for the institution } \\
\text { depend on units to } \\
\text { understand and } \\
\text { have buy-in to } \\
\text { institutional } \\
\text { strategic plan } \\
\text { - Budgeting for } \\
\text { academic and } \\
\text { non-academic } \\
\text { units will require } \\
\text { different formulas }\end{array}$ \\
\hline $\begin{array}{l}\text { Activity-based } \\
\text { funding }\end{array}$ & $\begin{array}{l}\text { - Preferred model } \\
\text { for smaller } \\
\text { institutions } \\
\text { - Can produce a } \\
\text { level of financial } \\
\text { accountability } \\
\text { within an } \\
\text { academic and } \\
\text { non-academic unit }\end{array}$ & $\begin{array}{l}\text { - Does not meet } \\
\text { complex needs of } \\
\text { a modern } \\
\text { university } \\
\text { - Can be difficult to } \\
\text { quantify certain } \\
\text { activities, in turn } \\
\text { stifling innovation } \\
\text { and growth }\end{array}$ \\
\hline $\begin{array}{l}\text { Performance-based } \\
\text { funding }\end{array}$ & $\begin{array}{l}\text { - Can create } \\
\text { incentivization for } \\
\text { activity and } \\
\text { positive growth in } \\
\text { the short-term }\end{array}$ & $\begin{array}{l}\text { - Long-term benefits } \\
\text { of model are not } \\
\text { definitive } \\
\text { - Incentivizes units } \\
\text { to meet centralized } \\
\text { performance } \\
\text { factors as opposed } \\
\text { to its own unit } \\
\text { growth }\end{array}$ \\
\hline
\end{tabular}




\begin{tabular}{l|l|l}
\hline Model & Strengths & Weaknesses \\
\hline Centralized funding & $\begin{array}{l}\text { Good for } \\
\text { institutions that } \\
\text { are not focused on } \\
\text { stability or } \\
\text { continuity }\end{array}$ & $\begin{array}{l}\text { Rigid and can be a } \\
\text { roadblock to } \\
\text { change } \\
\text { - Usually requires } \\
\text { additional funding } \\
\text { models to enable } \\
\text { flexibility in time } \\
\text { of high needs }\end{array}$ \\
\hline
\end{tabular}

The models summarized above are intended to give institutions an overall understanding of what exists as financial modeling options, but, in reality, every institution uses a combination of these models best suited for their own special circumstances, strategic objectives, culture, and history. At the heart of which combination/hybrid will be best fitted will depend on eagerness and willingness to bring in and implement change, especially in these times of significant disruption mainly due to COVID-19.

It is also worth noting that while the COVID-19 pandemic has necessitated the renewed need to look at operations differently, it is not the cause of many changes that we need to consider. COVID-19 has only removed any excuses and barriers that previously prevented us from not recognizing the need to change institutionally. Universities that aspire to greatness must eagerly embrace change. In the future, successful universities will be defined by the ability to meet emerging challenges. In this regard, such institutions will add to their record of success by mobilizing their strengths - research and scholarship and purposeful in-depth teaching and learning - in new ways and with a clear and accurate understanding of the world. Relevance is defined in global terms, not regional or national. Impact is measured against higher standards not just of academic learning, but also of contribution to society's well-being. Our ability to recognize those strengths and areas for improvement, then align them with the needed funding and flexibility will remain paramount. To do this, research universities need to understand and build out their strategic objectives - regardless of budget model - and implement the funding model that allows for that growth in the short-term and long-term but empowering an entire community.

\section{Budget Model for a Growing Modern University}

An institution can allocate funds in a way that maintains the status quo, seeks incremental growth, or dedicated to continuous growth for global impact.

The following principles are an important guide that administrators should adhere to in the development and implementation of their model.

\subsection{Principles of the Model}

Academic excellence: Consistent with the University and Faculty strategic plans, academic excellence and quality learning experiences for students will be at the forefront of every decision made within the budget model. This necessarily implies that students will learn in the Faculty that makes most sense to their overall academic program.

Clarity: Methodologies, record keeping and key processes in the new budget are clearly communicated and understood.

Collaboration: The budget is developed, implemented and supported through collaborative and consultative relationships and structures.

Efficiency: Revenue will be allocated and used to support existing and new resources, structures and processes, and all Faculties and Academic Support Units will be mindful of reducing and containing costs.

Long term budget planning: The budget model will incorporate budget planning at all levels of the institution with a longer-term outlook.

Risk management and flexibility: The budget model will include mechanisms to minimize negative impact from changing funding, enrolment or costs and be able to allow an optimal and nimble response to unanticipated or unfavorable funding conditions.

Strategic alignment: The budget model will support the approved overall strategic direction of the university and will align with the academic support required, Faculty and strategic plans.

Support for strategic initiatives: The budget model will ensure that there is a reserved portion of revenues available to stimulate and develop strategic initiatives and institutional priorities guided by clearly articulated academic and business plans.

Transparency and accountability: The University will have a transparent resource allocation process across the Faculties and Academic Support Units with clear data analysis and evidence to support decision making.

It is advisable for the university to use an accounting principle known as "Fund Accounting" where money is segregated in several different Funds, depending on their source and purpose.

Most Funds, including Research, Trust and Endowment, have very specific purposes attached to them instructing administrators on the way that the University must spend that money as prescribed either by legislation or by agreements with the granting agency or donor.

The Fund that is the largest, and the one where the university has the most flexibility on spending, is the Operating Fund. Because of its size and flexibility, this is the fund where the university must develop its funding model. 


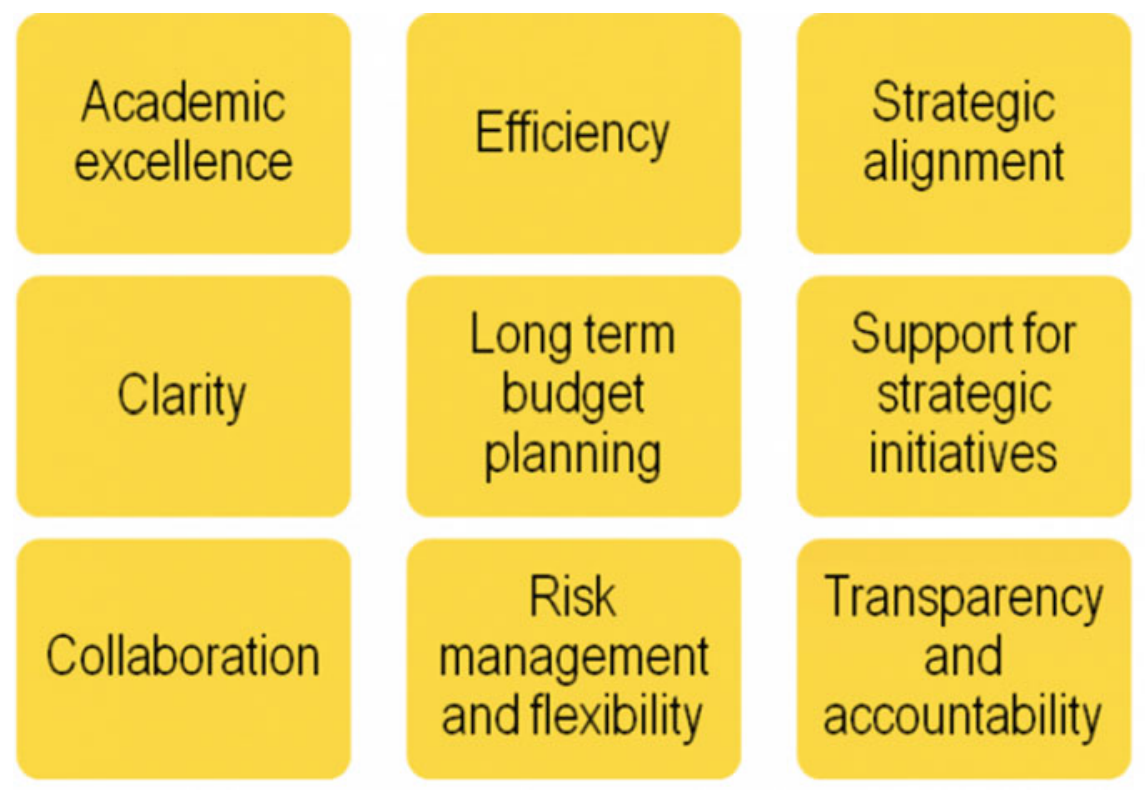

\subsection{Description of Funds Within a Budget Model}

While there is a dedicated Operating Fund that oversees the majority of university expenses, there are several Funds that help universities categorize their budgetary and resource needs.

Operating Fund: The Operating Fund is used for the majority of expenses including faculty and staff salaries, utilities, student support, and supplies. The two major sources of revenue that contribute to the Operating Fund are the government grants and student tuition fees. The student fees are mostly applicable to undergraduate fees as for many research intensive universities, given significant research and scholarship support for graduate students, the tuition income from graduate studies, at best, can be neutral.

Research Fund: The largest Fund, after the Operating Fund, is Research. When money is given to the university for research purposes, the terms of use are very clearly spelled out; the university ensures that the Research Fund is spent for the purposes intended by the granting agent.
Trust Fund and Endowment Fund: The university has many trusts and endowments, most of which support scholarships, Chairs, and student activities. As with the Research Fund, the university acts as a trustee for these monies, and must ensure that spending is in accordance with the specific Terms of Reference for that donation.

Capital Fund: Outside of operating and research fund, money is set aside specifically to support building repairs and related maintenance and alterations.

Ancillary Fund: Ancillary enterprises include non-academic sources such as Housing and Residences, Retail Services, Food Services and Parking; revenues earned are placed into this fund. The ancillary enterprises pay the university for space, utilities, administrative services, and maintenance from the revenues they receive.

University Fund: A special pocket of funds, raised through a taxation process for each Faculty, is used to fund strategic initiatives proposed by deans. The decision for the allocation of these funds are made by a committee comprised of the President, Provost, Vice President Finance and Vice President Research through a transparent process held twice a year. 


\section{FUND DISTRIBUTION OF A TYPICAL RESEARCH \\ UNIVERSITY}

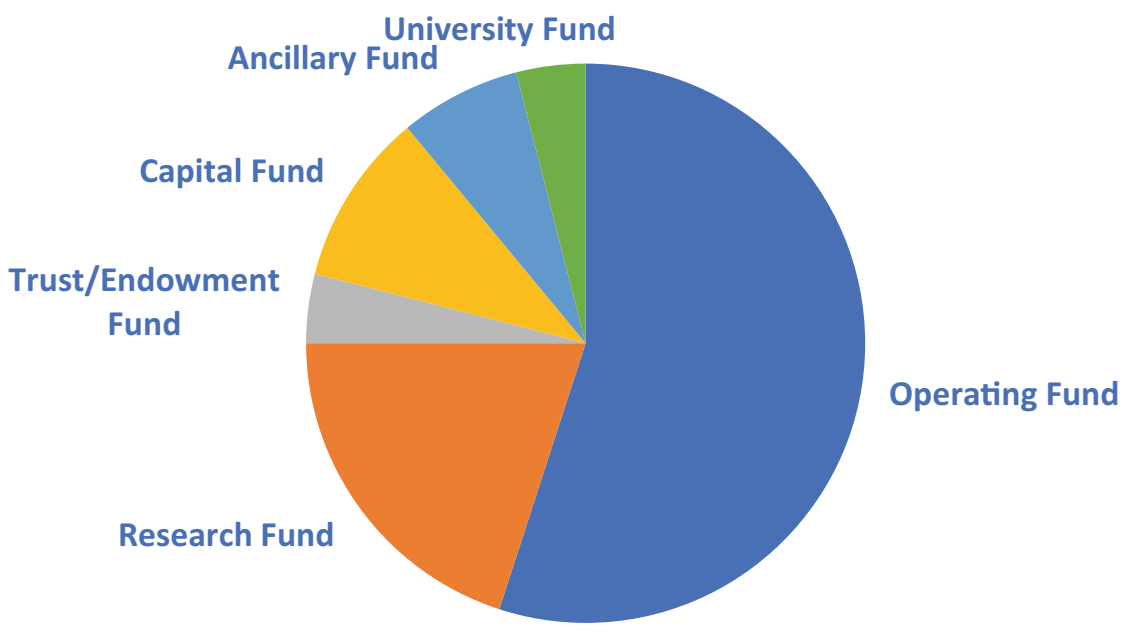

Allocation of Operating Fund: In this Budget Model, the process describes how the Operating Fund revenues are allocated to Faculties, Academic Support Units, and the University Fund. Within a given Faculty, the model does not describe how money flows to Academic Departments or Schools; the internal allocation of funds is at the discretion of the Faculty which is congruent to the principles of de-centralized funding model. The following chart illustrates the process, from source to sink how funds are allocated.

\section{Strategic Objectives and Plan for Research Intensive Universities}

Implementing the funding model of choice is only the first step for universities in making funding decisions. Before injecting money and resources (i.e. expertise, logistics support, etc.), governments and institutions themselves first need to assess their strengths and areas for growth in order to build strategic objectives. At the heart of any university




should be a guiding document of a strategic plan that aids in making key choices by setting short and long-term priorities.

We will detail the process for developing a comprehensive strategic plan as it will act as a guide for a research university. Before going in depth into the process of developing a plan, it is important to stress the importance of utilization. For funding decisions to have the effects they are intended to have, they must be made with a coordinated and long-term view. While small and large internal and external shifts in institutional, national, and global economics will occur-as we are currently experiencing with COVID-19having an active strategic plan will inform university leaders and their governing bodies of where their funding priorities should lie. Without those overarching pillars of focus an university may be susceptible to swings in priorities with every disruption that may come about.

A well-developed strategic plan that is actually implemented and evaluated at regular intervals allows for continuous improvement and consistency.

\subsection{Building with Your Community}

The development of a university strategic plan is not something that should be done with a top-down approach. The size and scope of a modern university is too complex and too diverse for a one-sided plan to properly address the needs of an entire community. To do this, every institution must engage with their entire university community.

As laid out in a study of university strategic plans comparing Hong Kong universities with elite institutions in the United States of America, many strategic plans are developed from the view of senior academic administrators [5]. While engaging discussions at the highest levels of authority is important, this severely limits the scope and possibilities of ideas that can be added to the strategic plan.

Students, faculty, postdoctoral researchers, staff, alumni, governing bodies (i.e. Boards of Governors, Senate), and the broader community of partners and supporters (i.e. industry partners, local government) all should have a voice in the plan and also see themselves inside of it. For example, during the recent development of the University of Waterloo 2020-2025 Strategic Plan, Connecting Imagination with Impact, the university set out on broad consultations that included participation and feedback from more than 3,500 members of the university community making it "everybody's" plan.

Building a broad base of collaboration brings with it a commitment of time and resources, but it ultimately results in a sizable range of institutional and community support to implement the plan. As Chan argues in their study of university strategic plans, "strategic planning needs resources to support and develop."[6]. Once that plan is developed that includes key performance indicators (KPIs) to track, an implementation plan is needed to gauge when and how an organization will need their targets and what resources need to be committed and where across the university.

\subsection{Implementation of Plan}

A plan, while vital to long-term growth, is only as strong as its implementation plan. Developing an implementation plan depends on the goals it has set out. We will delve into the process of crafting those goals, first.

Strategic plans can come in many different shapes, sizes, and level of complexity. Typically, they are formed around a set of themes or pillars. For example, these themes could revolve around research, teaching, and entrepreneurship. These themes are meant to be broad yet will focus an organization on these core ideas.

It is, again, important to recognize that many strategic plans end up sitting on a shelf never utilized if there is no university-wide buy-in, continuity, and reporting on progress through sound accountability measures. Building KPIs, an implementation plan that is appropriately funded, and creating an accountability framework that is designed into the plan makes achievement more likely.

\subsection{Empowering Academic and Non-academic Units}

Utilizing a funding model across a university that incentivizes innovation and personalization is essential to avoid institutional stagnation. As previously discussed, there are several budget and funding models - including a combination of more than one - that can be utilized. What we have observed at several institutions (and, most directly at the University of Waterloo) has strengthened outcomes is the de-centralized model that funds each academic and non-academic unit based on a formula that combines needs, research objectives, and enrollment with an ability to have access to additional funds for "out of the box" strategic initiatives. The unit controls those funds and uses them as they see fit to achieve their own goals.

What is important in this de-centralized model is how the academic unit uses their budget to also meet the goals of the university's overarching institutional strategic plan. This encourages the academic unit to utilize the institutional goals to help develop and guide their unique objectives in a cascade fashion and the creation of their own strategic plan. An example of this can be found at my institution where Faculty of Engineering developed their own strategic plan on the basis of the institutional plan [3]. The Faculty uses similar language and areas of focus as the central plan, but have 
crafted five key priorities that are unique to their needs and they have the control of the resources to achieve their research, teaching, and impact goals.

Select non-academic units can also opt to develop their own strategic plan, but given their smaller scale, some choose to develop a mandate letter with the core administration to ensure their budget commitments align with the core strategic goals of the university.

Funding the needs of the unit should not be dictated line-by-line like the centralized funding model, nor by the limiting incremental model or the unpredictable zero-based model. With that said, there must be financial accountability designed within the de-centralized model tied to milestones and the incorporation of institutional strategic goals [7]. To meet the objectives of an ambitious 5-year strategic plan, the academic and non-academic units need consistency, a healthy degree of autonomy, and the incentivization to push forward and grow exponentially.

To spur growth, however, a university must continue to explore new funding sources outside of tuition and government subsidies as this will encourage long-term partnerships and innovation by encouraging universities to collaborate.

\section{Aligning University's Key Differentiators with External Funding Sources}

Every university has unique differentiators that set them apart from other peer institutions. Strengthening and expanding those differentiators is important for any research university but doing so means acquiring the resources to do just that. Universities also cannot expect or anticipate public funding for all of their needs. For more than a decade funding for universities in places like those in the United States has declined by $28 \%$ [8]. This challenge will only be exacerbated in the coming decade with the sharp rise in national deficits due to COVID-19. To help close that gap for research universities, the development of external funding sources is more essential than ever to meet organizational goals and increase impact.

It is important to first align those differentiators with external funding sources, such as industry partners, alumni donors and general non-government investments in research. This section will outline a few of the core areas of consideration when assessing the alignment of differentiators, funding sources, and expected outcomes.

\subsection{Aligning Priorities Between Partners}

There are several layers to assessing an institution's research priorities from a centralized view and also that of a single academic unit. As mentioned previously, a university can set out ambitious strategic goals for the entire university and empower their academic units to develop their own targets and areas of interest, and fund said targets with a measure of latitude. Studies of external research funding, however, have shown that without proper alignment between strategic, research priorities, confusion and the loss of productivity/impact of the external funding partner can ensue [8]. This makes the assessment of research priorities from top-to-bottom before funding decisions are made, vital to overall success.

Research priorities are not just focused on the disciplines or subject areas of a university. Funding for biomedical, mechatronics engineering, and other core areas of research impact are important to assess, but also too is the spectrum of what projects to include at the fundamental research level and all the way to commercialization of intellectual property (IP) level. Funding each of these areas is important to the overall strength of a university as they have the potential to display the innovation pipeline possibilities from beginning to end. How much and in what fashion a university funds these areas through external funds will often determine what external partner would be interested and willing to support.

Reaching out to industry partners to begin exploratory discussions around specific needs in the sector is the first step in discovering solutions that can be offered and the funding available. This is valuable in the efforts to glean industry trends that university researchers may not be privy to in their day-to-day work. This synergistic view of university differentiators allows for a larger offering to potential external funders that complement the research priorities of the university.

It should also be recognized that key differentiators are not exclusive to a research discipline, piece of equipment, or facility. A university's students-at the undergraduate and graduate levels - are unique in and of themselves that can offer strength to bringing in external funding.

\subsection{Entrepreneurship, Commercialization, and Intellectual Property}

An additional factor that must be considered when developing external funding partners is the role of commercialization, intellectual property (IP), and the broader entrepreneurial possibilities. For a modern university to ignore the practical applications of the new knowledge, discovery, and innovation being created by its researchers is a loss to society and the global community. A challenge to seeking research partnerships often stems from ownership of the IP being developed.

Many universities in the United States, Canada, and around the world use an IP policy that inserts the institution 
right in the middle of the ownership of the research. The logic of the university is that if the IP was developed using their facilities by those employed at the institution, the university has ownership rights to said research. In these examples, the university is inserting itself into a partnership between the researcher and the external funder, disincentivizing the commercialization of the IP for the researcher and the partner. This does not have to be a conflict.

Implementing a creator-owned IP policy takes the university out of the equation. It allows for a continued expansion of industry partnerships due to increased incentivization to work with a university's researchers and even for those researchers to launch their own ventures.

While a creator-owned IP policy makes it so that the university does not financially benefit from an ownership stake in the IP or business being developed, it does break down barriers that allow students, researchers, and industry partners from commercializing their research. In turn, the businesses that are created can become dedicated donors to the university, future employers of students and graduates, and an economic engine for the region and nation.

\subsection{Importance of External Funding Sources}

External sources of funding have long been an important part of a research university's revenue. This is for many of the reasons above, but also for the simple need of having diversification of funding to hedge against shifts in societal or economic norms. For example, changes in government, national and global recessions, and geopolitical shifts that hurt trade all have impacts on the ability of state-supported universities to sustain their research activities, let alone grow them.

Two separate reports from Springer point to the importance of incorporating external research funds to the ongoing strength of universities. An analysis of project-based research funding found that "the success and prestige of university are increasingly linked to its ability to garner external funds" [9] and at the same time the university's ability to garner outside funds shows that it enhances the external view of the institution without sacrificing academic freedom or university autonomy away from national support [10].

Universities need to incorporate external funding sources such as industry partners, but to do so effectively they need to do so with internal alignment of priorities, strategic goals, and their unique differentiators or risk limiting growth and impact.

\section{Making Choices in the Time of COVID-19}

The COVID-19 pandemic has been mentioned several times throughout this analysis of funding models. It is an unavoidable, disruptive force that will have short and long-term impacts on research universities, regardless of size. It will impact the number of students who attend university. It will impact the number of graduate students and their scope of projects due to diminishing funding opportunities. And, it will simply mean fewer resources from both public and private sources.

COVID-19 has put enormous financial pressure on governments and businesses of all sizes, stunting the ability to invest the needed resources into research and scholarship. Two aspects of funding and budgeting for a modern, 21st-Century university have been discussed in depth-internal models and aligning with external funding sourcesand it is important to assess what further impacts COVID-19 will have on decision making around both.

\subsection{Internal Models During COVID-19}

Those institutions that were utilizing more rigid or dynamic models of funding, such as centralized, incremental, or zero-based funding will be faced with many difficult decisions in the coming months and years. COVID-19 will be changing the research priorities for nearly all research-intensive universities, regardless of whether they have a medical school or not. Health care and health related scholarship will be a primary focus for many institutions for the simple fact that this research is now more essential than ever. The United States alone has committed $\$ 1.25$ billion (USD) to research institutions as part of the first stimulus package [11]. Similar investments in health care research have been made in Canada and the European Union.

A funding model that allows flexibility to change at the macro and micro level will provide universities and their academic research units with the needed agility to respond to shifts in research demands without a draconian shift from the top, thus alienating those researchers who feel left out from the shift. Each academic Faculty can be empowered to find their own way to develop their own view of how to address the ripple effects of COVID-19 across our society.

\subsection{External Funding for Research During COVID-19}

Research funding will need to come from collaboration now more than ever. Resources at the government level will likely face significant restrictions in 2021 and beyond as 
national budgets adjust to record-breaking deficits. Corporate budgets, too, will face similar restrictions as many continue to grapple with cash-flow issues of their own. This will mean that national and international collaborations will become even more important to develop, even as they become logistically more challenging.

The natural inclination for nations during times of disruption and restriction, like now, is to become enclosed. Research universities must fight this inclination and instead embrace new forms of partnerships. This can include cross-border research projects, such as the ones in which KAU and its partners are involved. Each party sees an alignment and also the benefits of pursuing a cross-border collaboration, even as borders become harder to physically cross.

It is impossible to avoid the effects of COVID-19, but now is the time to build flexibility and exploration into budgeting and funding. Ensuring there is an agreement on strategic direction internally and reaching out externally to new possibilities, both in research and in development of new discoveries, the time during and after COVID-19 will continue to be productive.

\section{Conclusion}

Ensuring a university is appropriately funded will always be vital to the success of an institution, but it is also important as to how those funds are dispersed internally and aligned with overall strategic objectives. Making those choices comes down to the series of choices at the disposal of administrative leaders. It is their duty to build trust amongst their academic and non-academic community or risk the challenges that comes from a disconnected or centralized university.

There must be a balance and that balance is dependent on establishing and building trust, empowerment, and ultimately accountability within the institution. Without these three factors a modern, 21st-century research university will remain a step behind, regardless of how much money is committed to its success.

\section{References}

1. J. Wetherbe, J. Montanari, Zero based budgeting in the planning process. Strateg. Manage. J. 2(1), 1-14 (1981). https://www.jstor. org/stable/2485987

2. J. Leitzel, C. Corvey, D. Hiley, Integrated planning and change management at a research university. Change, 33(1), 36-43 (2004). https://www.jstor.org/stable/40177242

3. S. Rowe, Aligning the budget model to strategic goals: executive-level decision points to ensure impact on cost, growth, and strategy. Business Affairs Forum, EAB (2006), 5
4. I. Liefner, Funding, resource allocation, and performance in higher education systems. High. Educ. 43(4), 469-489 (2003)

5. A. Chan, A genre analysis of the strategic plans of higher education institutions in Hong Kong and the United States of America (Professional Communication, Hong Kong University Press, 2009), pp. 53-69, 66. http://www.jstor.com/stable/j. ctt1xwb74.8

6. The Epicentre of Technology Talent. https://uwaterloo.ca/ engineering-strategic-plan-2020-2025

7. J.W. Dean, American colleges and universities. The insider's guide to working with universities (University of North Carolina Press, 2019)

8. R. Raudla, E. Karo, K. Valdmaa, R. Kattel, Implications of project-based funding of research on budgeting and financial management in public universities. High. Educ. 70(6), 957-971 (2015). www.jstor.org/stable/43648918

9. L. Chiang, The relationship between university autonomy and funding in England and Taiwan. High. Educ. 48(2), 189-212 (2004). https://doi.org/10.1023/B:HIGH.0000034314.77435.bf

10. Massive U.S. coronavirus stimulus includes research dollars and some aid to universities, March 25, 2020. https://www. sciencemag.org/news/2020/03/massive-us-coronavirus-stimulusincludes-research-dollars-and-some-aid-universities

11. A. Wall, R. Frost, R. Smith, R. Keeling, Examining a higher education funding formula in a time of shifting currents: Kentucky's benchmark approach. J. Educ. Fin. 33(3), 221-237 (2008)

Prof. Dr. Feridun Hamdullahpur has served as the President and Vice-Chancellor of the University of Waterloo since 2010. Dr. Hamdullahpur earned an M.Sc. (1979) in Mechanical Engineering from the Technical University of Istanbul and a Ph.D. (1985) in Chemical Engineering from the Technical University of Nova Scotia (TUNS). He was appointed Assistant Professor (1985) at TUNS at the Center for Energy Studies, Associate Professor in TUNS's Department of Mechanical Engineering (1990) and later full Professor of Mechanical Engineering (1995). Dr. Hamdullahpur is currently a Professor in the Department of Mechanical and Mechatronics Engineering at the University of Waterloo, while he serves concurrently as President.Throughout his career, Dr. Hamdullahpur has been an active researcher in thermo-fluids and energy engineering, a passionate teacher and an academic administrator. He has authored hundreds of scientific and academic publications and supervised over 50 graduate students. He was named a Fellow of the Canadian Academy of Engineering in 2014.As President of the University of Waterloo, Dr. Hamdullahpur has devoted his tenure to fostering excellence in academics and research, with a dedication to developing an innovative culture committed to experiential education. Through President Hamdullahpur's stewardship, the University of Waterloo has remained Canada's most innovative university for 27 consecutive years.His current focus at the University of Waterloo is expanding its lead in innovation, building on Waterloo's long-standing and emerging strengths in co-operative education, research, entrepreneurship, and equity.The President continues to serve in many roles on committees and boards. He has been Chair of the Waterloo Global Science Initiative since 2016, an active member of the Sorbonne Université Strategic Orientation Committee since 2014 and a member of the King Abdulaziz University International Advisory Board since 2017. The President is one of ten global university presidents named a United Nations HeForShe IMPACT $10 \times 10 \times 10$ champion selected to engage boys and men in the cause of gender equity. In acknowledgment of President Hamdullahpur's leadership in education and innovation, he was awarded the l'insigne de chevalier des Palmes Académiques by the French Republic in February 2019, the Queen Elizabeth II Diamond Jubilee Medal in January 2013, and a Fellow of the Royal Society of Canada in 2018.President Hamdullahpur is a member of the KAU IAB. 
Open Access This chapter is licensed under the terms of the Creative Commons Attribution 4.0 International License (http:// creativecommons.org/licenses/by/4.0/), which permits use, sharing, adaptation, distribution and reproduction in any medium or format, as long as you give appropriate credit to the original author(s) and the source, provide a link to the Creative Commons license and indicate if changes were made.
The images or other third party material in this chapter are included in the chapter's Creative Commons license, unless indicated otherwise in a credit line to the material. If material is not included in the chapter's Creative Commons license and your intended use is not permitted by statutory regulation or exceeds the permitted use, you will need to obtain permission directly from the copyright holder. 